\title{
Some Insights to the Reuse of Dredged Marine Soils by Admixing with Activated Steel Slag
}

\author{
Chee-Ming Chan ${ }^{1}$ and Ainun Nazhirin Abdul Jalil ${ }^{2}$ \\ ${ }^{1}$ Faculty of Engineering Technology, Universiti Tun Hussein Onn Malaysia, 86400 Batu Pahat, Johor, Malaysia \\ ${ }^{2}$ Faculty of Civil and Environmental Engineering, Universiti Tun Hussein Onn Malaysia, 86400 Batu Pahat, Johor, Malaysia \\ Correspondence should be addressed to Chee-Ming Chan; chan@uthm.edu.my
}

Received 4 May 2014; Revised 13 July 2014; Accepted 16 July 2014; Published 5 August 2014

Academic Editor: Hossein Moayedi

Copyright (c) 2014 C.-M. Chan and A. N. Abdul Jalil. This is an open access article distributed under the Creative Commons Attribution License, which permits unrestricted use, distribution, and reproduction in any medium, provided the original work is properly cited.

\begin{abstract}
Regular dredging is necessary for the development of coastal regions and the maintenance of shipping channels. The dredging process dislodges sediments from the seabed, and the removed materials, termed dredged marine soils, are generally considered a geowaste for dumping. However, disposal of the dredged soils offshores can lead to severe and irreversible impact on the marine ecosystem, while disposal on land often incurs exorbitant costs with no guarantee of zero-contamination. It is therefore desirable to reuse the material, and one option is solidification with another industrial waste, that is, steel slag. This paper describes the exploratory work of admixing dredged marine soil with activated steel slag for improvement of the mechanical properties. An optimum activation concentration of $\mathrm{NaOH}$ was introduced to the soil-slag mixture for uniform blending. Specimens were prepared at different mix ratios then left to cure for up to 4 weeks. The unconfined compressive strength test was conducted to monitor the changes in strength at predetermined intervals. It was found that the strength does not necessarily increase with higher steel slag content, indicating an optimum slag content required for the maximum solidification effect to take place. Also, regardless of the slag content, longer curing time produces greater strength gain. In conclusion, steel slag addition to dredged sediments can effectively strengthen the originally weak soil structure by both the "cementation" and "filler" effects, though the combined effects were not distinguished in the present study.
\end{abstract}

\section{Introduction}

In the modernization effort of the country, development of the coastal region is inevitable for a country with a rich maritime history like Malaysia. The developing works in coastal areas involve dredging works for construction of structures, such as ports, waterways, and breakwaters, land reclamation, and widening sections of river or sea to facilitate economic activities and to erect coastal protection systems. Perhaps the less well-known but equally important purpose of dredging is the maintenance of port facilities. Dredging works at sea may be defined as the transfer process and removal of soil at the bottom of the sea to increase the sea depth, with the main purpose of keeping harbours and waterways accessible [1], where the area of dredging activities may consist of ponds and lakes, rivers and river mouth, port and harbours, and bays and inlets.
Apparently, dredging is necessary for the development of coastal area, especially in solving sedimentation problems caused by natural processes or manmade activities. It is also crucial in providing appropriate water depths and turnings at waterways to maintain the viability of a maritime economy. However, the dredging process can also cause negative impact on the environment, especially when the dredged soils are dumped into distant marine waters. Dumping activities from the dredging works could adversely affect the physical and biological elements of the sea. Contaminated dredged soils are harmful and could degrade the marine environment and result in long term, irreversible damages.

Therefore, if a reuse potential can be derived for the dredged soils, dumping can be avoided and the environmental and ecological impact can be avoided. As the dredged soils are usually of the fine-grain soil type, that is, clay and silt, they 
Table 1: Dredging and dumping effects [7].

\begin{tabular}{|c|c|c|c|}
\hline Effects & Issues & Impact & Concerns \\
\hline \multirow{5}{*}{ Short terms } & $\begin{array}{l}\text { Turbidity: settlement of soils and } \\
\text { materials }\end{array}$ & Blanketing & $\begin{array}{l}\text { Navigation, fishing activity, and nature } \\
\text { conservation of benthos }\end{array}$ \\
\hline & Turbidity: water column & Water quality & $\begin{array}{l}\text { Fish movement, nature conservation of } \\
\text { contaminant }\end{array}$ \\
\hline & Removal of benthos and other species & Food chain & Fish food \\
\hline & Removal of artifact & $\begin{array}{c}\text { Disturbance of } \\
\text { archaeological sites }\end{array}$ & Loss of archaeological sites \\
\hline & Operational effects & Oil spills, noise & $\begin{array}{l}\text { Navigation, fishing activity, and nature } \\
\text { conservation of benthos }\end{array}$ \\
\hline Long term & Altered bathymetry & $\begin{array}{l}\text { Waves, sedimentation, and } \\
\text { erosion }\end{array}$ & $\begin{array}{l}\text { Coastal deference, habitats of animals, } \\
\text { fish resources for fisheries, archaeological } \\
\text { sites, and navigation }\end{array}$ \\
\hline
\end{tabular}

possess the typical characteristics seen in similar soils found on land. These soils are generally low in bearing capacity and high in compressibility, making them unsuitable for use as a sound geomaterials in civil engineering applications, such as backfilling. Thus, the dredged soils need to be pretreated prior to application, and a possible solution is to improve the strength properties with solidification.

According to website of Nippon Slag Association [2], steel slag is a steel-making waste that could remain in the environment for hundreds of years because it cannot be decomposed to anything else at temperatures that exist in nature. Due to the slag's hardness and likeness to naturally sourced aggregates, steel slag has found its way into reuse in many engineering works, though some remain unusable for contamination issues [3]. Steel slag is also known for its solidification properties, such as those reported by Poh et al. [4].

The present study involved admixing an electric arc furnace steel slag with a dredged marine soil collected from the east coast of Peninsular Malaysia. The slag was first activated with $\mathrm{NaOH}$ to enhance the solidification potency. It was hypothesized that if the slag could effectively improve the strength of the dredged soil, it could be reused as an ordinary soil with reasonably good engineering properties. This could help reduce dumping of the material offshore and avoid the negative impact associated with the disposal method, not to mention the added benefits of creating a sustainable solution to the otherwise discarded materials.

\section{The Environmental Effects of Dredging}

The main environmental effects of offshore dumping of dredged soils are the seabed blanketing or smothering, which causes destruction of the habitat of plant, coral, and other species living in the sea. Blanketing or smothering also causes stress, reduces growth, and causes fatality of marine creatures, inadvertently affecting the livelihood of fishermen [5]. Dredged soils from nearshore structures like ports and harbours can potentially contain a variety of harmful materials, such as heavy metals, oil, and grease as well as pesticides. The dredging processes inevitably release these contaminants in the sediments into the water column, with effect on the immediate vicinity towards the aquatic food chain and creating contamination and poisoning risks to humans [6]. The effect of dredging and dumping works can be categorized into short and long term effects. Table 1 summarizes the effects of dredging and dumping [7].

\section{Reuse Potential of Dredged Soils}

As mentioned earlier, the reuse of dredged material could help reduce the volume of disposal. However, to determine the suitability of dredged soils for reuse, few considerations have to be monitored, such as the contamination of the disposed materials, environmental acceptability, cost and benefits of treatment and reuse, and the law and regulations involved. Evaluating the contamination of the dredged material is the first step to determine if the material is acceptable for reuse. Nonetheless, the reuse of dredged marine soils as they are is not unheard of, though the contamination risks must first be ascertained. Based on the studies of Lindmark et al. [8], the stabilized soils can be used as filling material in ports as the replacement for conventional filling material. Siham et al. [9] found the treated material to be usable in the road engineering as subbase and base course materials. Besides, the dredged marine soils have been successfully implemented in natural habitat restoration and development, beach nourishment, park and recreation, aquaculture, surface mine reclamation, and other construction or industrial developments [10].

\section{Steel Slag}

Steel slag is a steel-making waste from the steel industry and is reused as it is in many engineering fields, including transportation and highway engineering, environmental engineering, and geotechnical engineering. It is used as either an additional or substitute material in road construction, filter or soil stabilizer in these cases. Indeed, soil stabilization using steel slag is popular in Europe and Asian country as a result of a concerted effort towards reducing wastes and optimizing resources. 
Steel slag can be produced from 2 different processes, namely, from the conversion of iron into molten iron and from the manufacturing process to modify the components of molten iron in making strong steel. The byproducts of the processes can be categorized as the blast furnace slag and steel-making slag. There are two types of blast furnace slag, that is, the air-cooled slag and the granulated slag. Steel-making slag includes the converter slag and electric arc furnace slag. Regardless of the processes to produce the slags, their size and shape are similar, though they have different chemical and mechanical properties. For instance, steelmaking slag has a lower specific gravity than blast furnace slag, while electric arc furnace slag is usually darker than the other types of steel slag.

Blast Furnace Slag. In the production of iron, blast furnace slag and basic oxygen furnace slag are generated. Both types of slag are produced in the blast furnace, where it rises above molten iron due to its specific gravity of being less than that of molten iron. This enables ease of separation of the slag from the furnace. Upon removal from the furnace, the cooling method used determines the type of slag produced. If the natural cooling process is used, with water being sprayed over the slag, it is categorised as an air-cooling slag. On the other hand, if a pressurized jet is used to make it cool rapidly, a granulated slag is formed.

Steel-Making Slag. The molten iron from a blast furnace will be processed to make strong steel. If a converter is used in the steel-making process, with water being sprayed on the slag for cooling purpose, the slag generated is termed a converter slag. The slag is categorized as an electric arc furnace slag if an electric furnace arc is used instead.

\section{Alkaline-Activation of Steel Slag}

Based on Shi [11], the cementing properties of activated steel slag using alkaline are higher than those of raw steel slag due to the chemical reactions between the steel slag and sodium hydroxide $(\mathrm{NaOH})$. It was reported that the cementitious properties increase under room temperature curing, with finer slag producing more significant strength increase.

The most commonly used alkaline activators are sodium hydroxide, potassium hydroxide, sodium water glass, and potassium water glass [12]. All these activators have some common properties: caustic, corrosive, and highly hazardous. Among these chemicals, $\mathrm{NaOH}$ arguably finds the widest use in industrial applications. This is attributed to both the low price and availability in various forms, that is, granules, flakes, or pellets. Wang and Yan [3] recommended the $\mathrm{NaOH}$ : steel slag ratio of $30 \%$, based on steel slag in dry condition and the $\mathrm{NaOH}$ in liquid form for mixing.

\section{Sampling and Preparation of Dredged Soil}

The dredged depth varies according to project area but the depth is usually at 3.5 to $15 \mathrm{~m}$ below the chart datum. The total dredged volumes depend on project requirement and could reach up to thousands of metre cubes. The dredged material,

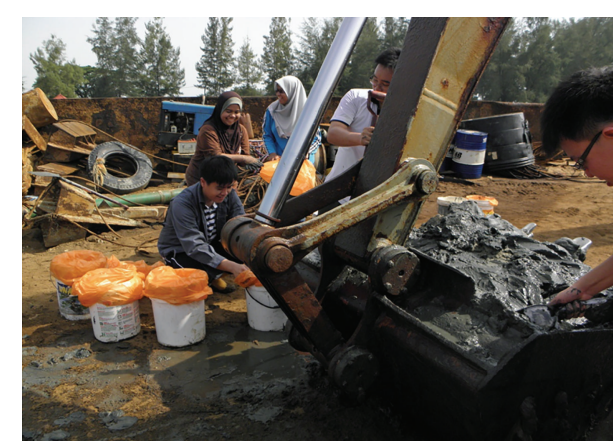

Figure 1: Sample collection from the backhoe dredger.

ideally, should be disposed of in contained facilities with appropriate monitoring. Nonetheless, offshore dumping has remained the most preferable disposal method worldwide. In this particular study, the dredged soil was designated for offshore dumping site 4 nautical miles from the shore.

The dumping process is categorized as temporary and permanent disposal. Temporary dumping usually involves transferring the dislodged material to a nearshore site via suction pipelines connected to the dredger. These temporary dump sites may eventually be capped and used as reclaimed land, though suitable environmental risk assessment may not be in place for the purpose. Permanent dumping sites, on the other hand, would receive the dredged materials soils from temporary dump sites or be transported directly from the dredged sites without temporary storage elsewhere.

The samples used in the present study were bulk samples collected immediately upon removal from the seabed. As a backhoe dredger was used for the dredging works, samples were simply scooped from the backhoe and stored in sampling bags for transportation to the laboratory (Figure 1). Considering that the soil samples were disturbed but representative of the field conditions, they were remoulded by manual and mechanical mixing prior to use in the test series. Note that in order to control the mixing water content when admixed with steel slag, the dredged soil was initially ovendried then crushed and ground to powder form for the solidification study. This enabled a careful control of the mix ratios of each constituent in the mixture, that is, soil, slag, and water contents.

\section{Admixing Dredged Soil with Steel Slag}

Ratio of Mixture. The mix ratio of the dredged soil and steel slag adopted was guided by past reports in similar studies (Table 2). It can be seen that most researchers used 10\% and more of steel slag addition, except for Manso et al. [14] who used no more than $5 \%$ slag in their work. Note also that, apart from Grubb et al. [15] and Manso et al. [14], the other researchers used slag alone in their attempts to solidify the soils. The present study adopted soil : slag ratios of $3: 7,5: 5$, 
TABLE 2: Steel slag contents in soil-slag mixtures.

\begin{tabular}{lccc}
\hline Reference & Soil type & Steel slag content & Other admixtures \\
\hline Liang et al. [13] & Silty clay & $10-30 \%$ steel slag & No cement added \\
Manso et al. [14] & Muddy clay & $4-5 \%$ steel slag & $2 \%$ lime, no cement added \\
Grubb et al. [15] & Marine clay & $20-80 \%$ steel slag & Slag cement added \\
Chan et al. [16] & Marine clay & $30-70 \%$ steel slag & No cement added \\
\hline
\end{tabular}

and $7: 3$, with all mixtures prepared at $40 \%$ water content (based on dry mass of the soil).

Slag Particle Size. The slag particle size is usually kept below $2 \mathrm{~mm}$ to ensure uniformity on the soil-slag specimens prepared. Large slag particles tend to create excessively strong but localized zones in the specimen. They are also prone to impede good mixing of the materials. As one of the most crucial success factors of solidified soils is the mix uniformity [17], the slag particle size must be kept proportionate to the specimens prepared for test in the laboratory. On a separate note, larger slag particles could contribute to more significant stiffness gain, as measured with an indirect or global displacement measurement system in the unconfined compressive strength tests. The finer slag particles, on the other hand, could induce more effective solidification due to the greater specific surface available for reactions. Stiffness could also be enhanced with fine slag particles inclusion, as the relatively denser slag particles fill the voids of the soil-slag mixture more effectively. The key chemical properties are as follows: $\mathrm{SiO}_{2} 36 \%, \mathrm{Al}_{2} \mathrm{O}_{3} 31 \%, \mathrm{Fe}_{2} \mathrm{O}_{3} 18 \%$, and $\mathrm{CaO} 0.76 \%$. Note the very small amount of free lime $(\mathrm{CaO})$ in the slag, which explains the poor self-cementing potency on its own.

\section{Tests on The Dredged Soil}

The physicochemical and mechanical properties of a dredged marine soil were determined using the same methods for ordinary upland soils. The physical properties tests included the particle size analysis using a conventional laser particle size analyser (Figure 2$)$, moisture content $\left(w_{\text {nat }}=118.5 \%\right)$, Atterberg limits and specific gravity $\left(G_{s}=2.95\right)$, and $\mathrm{pH}$ (2.95) tests. X-ray fluorescence test was used to identify the elemental composition of the soil, with the dominant element oxides found to be $\mathrm{SiO}_{2}$ and $\mathrm{Al}_{2} \mathrm{O}_{3}$, which constituted $57.65 \%$ and $23.43 \%$ of the dredged sample. The soil was classified as a low plasticity silt.

The undrained shear strength of the soil was determined with either the laboratory vane shear or unconfined compressive strength test. Note that the vane test was necessary for the natural soil sample, which was too soft to be formed into cylindrical specimens for the unconfined compressive strength tests. As reported by Chan et al. [16] and Grubb et al. [15], dredged marine soils of fine-grain nature dislodged from maintenance dredging are generally low in strength and exhibit characteristics of a soft clayey soil. Based on Das [18], the relationship between consistency and unconfined compressive strength of clay soils is as shown in Table 3.
TABLE 3: Relationship of consistency and unconfined compression strength $\left(q_{u}\right)$ of clays.

\begin{tabular}{lc}
\hline Consistency & $q_{u}(\mathrm{kPa})$ \\
\hline Very soft & $0-25$ \\
Soft & $25-50$ \\
Medium & $50-100$ \\
Stiff & $100-200$ \\
Very stiff & $200-400$ \\
Hard & $>400$ \\
\hline
\end{tabular}

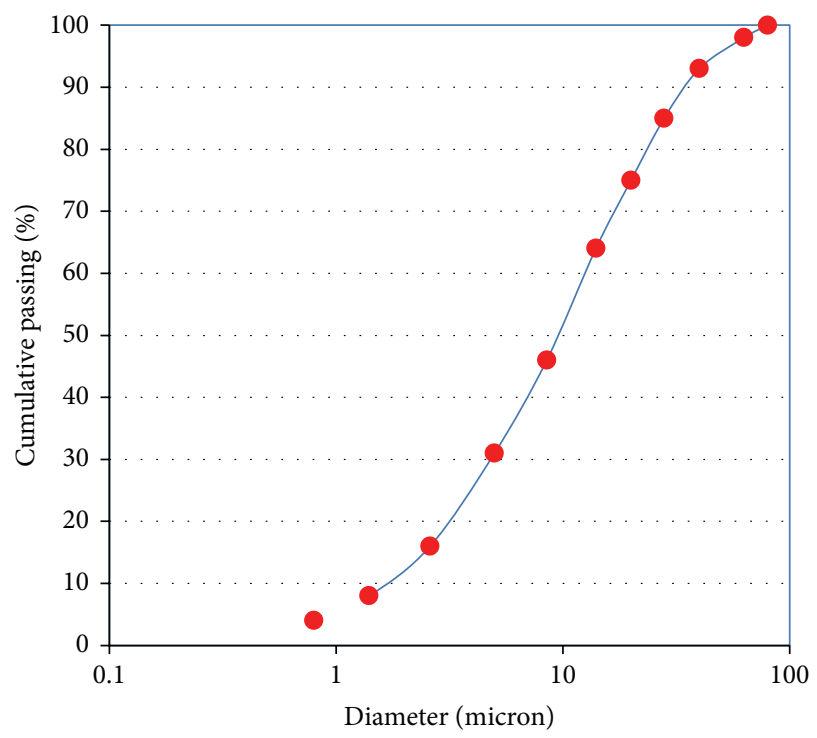

Figure 2: Particle size distribution of the dredged soil.

Unconfined Compressive Strength. The unconfined compressive test is designed for testing clay soils and is not applicable to cohesionless or coarse grained soils. This is understandable as a granular sample can hardly be made into standalone specimens for tests without lateral constraints. The unconfined compression strength $\left(q_{u}\right)$ is defined as the maximum unit axial compressive stress at failure. The test equipment consists of a loading frame, with the top plate attached to a load-measuring device (i.e., a proving ring or load cell), while the bottom plate is raised and lowered in the tests. The setup can be hand operated, electric motor-driven or uses a hydraulic load frame. Vertical deformations of the specimen are measured with a dial gauge or transducer, that is, the relative movement between the top and bottom plates. According to Lai [19], there is a number of sources of error in the unconfined compression test: the use of 


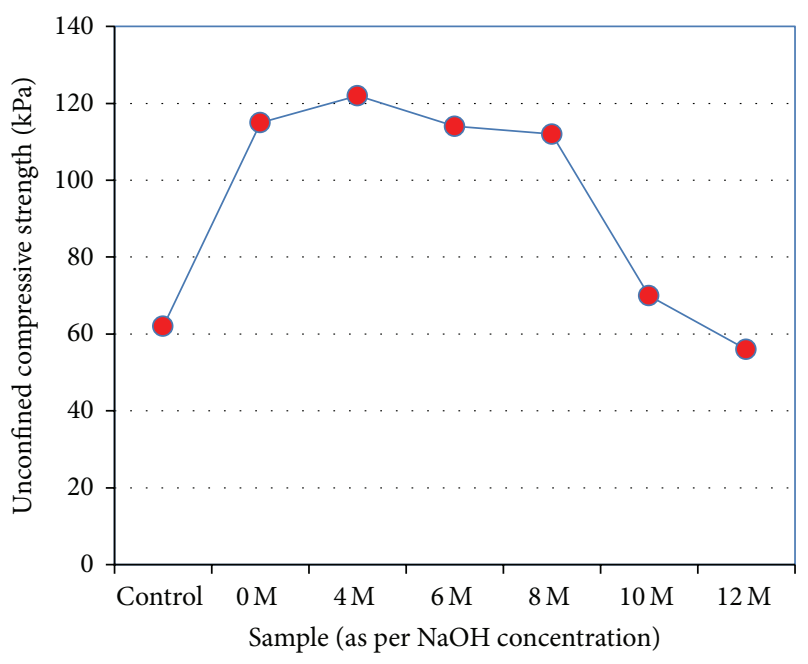

FIGURE 3: Effect of $\mathrm{NaOH}$ concentration on the resulting solidified 7 -day strength of soil-slag $(5: 5)$ mixture.

unrepresentative specimen, as in a short specimen; end effects caused by the gripping top and bottom loading plates, resulting in exaggerated strength of a specimen by preventing the formation of the weakest failure plane; and buckling of an overlong specimen, of which a length-to-width ratio of 2-3 is recommended to avoid this problem.

\section{Preparation of Test Specimens}

The dredged marine soils were first placed in thin layers in metal trays and dried in an oven at $105^{\circ} \mathrm{C}$ for 24 hours. The dried soil was next crushed and ground into fine particles passing the $425 \mu \mathrm{m}$ sieve. The steel slag particles used in the present study were kept below $2 \mathrm{~mm}$ to avoid disproportionate particle and specimen sizes. The dredged marine soil was solidified using 3 different ratios, that is, soilto-slag ratios of $3: 7,5: 5$, and $7: 3$.

To determine the suitable concentration of $\mathrm{NaOH}$ for optimum activation of the steel slag, preliminary tests were conducted for specimens of 5:5 mix ratio and left to cure for 7 days before the unconfined compressive strength test. The $\mathrm{NaOH}$ was prepared at different concentrations of 4 , $6,8,10$, and $12 \mathrm{Mol}$. The mixing water content wax fixed at the $36 \%$, which was between the liquid and plastic limits of the soil. Control specimens with no slag addition were also prepared for comparison purposes. Based on the preliminary test results (Figure 3 ), the optimum molarity for $\mathrm{NaOH}$ was found to be $4 \mathrm{Mol}$. The strength of the soil without slag addition was barely $60 \mathrm{kPa}$, and the increment at 5:5 mix ratio after 7 days was more than double, that is, $120 \mathrm{kPa}$. Higher concentration of $\mathrm{NaOH}$ appeared to be detrimental to the strength enhancement of the soil-slag mixture, possibly due to the unfavourable $\mathrm{pH}$ for solidification to take place effectively. Indeed, specimens with $9 \mathrm{Mol} \mathrm{NaOH}$ and above suffered a dramatic drop in strength. By $12 \mathrm{Mol}$, it has reverted to the untreated soil's strength of about $60 \mathrm{kPa}$, clearly indicating the negative impact of excessive concentration of the activator used.

\section{Results and Discussions}

Figure 4 illustrates the compression curves as derived from the unconfined compressive strength tests conducted on the soil-slag specimens on 3, 7, 14, and 28 days of age. Overall, all mixtures of dredged soil and activated steel slag resulted in strength improvement, albeit to different degrees. Considering that the untreated soil at the same water content recorded $q_{u}$ of slightly less than $60 \mathrm{kPa}$, the slag addition, regardless of the mix ratios, was effective in solidifying the soil.

For the 7:3 specimens, the threshold curing period for maximum strength improvement in a month appears to be 14 days. As shown in Figure 4(a), the strength did not undergo much change between 3 and 7 days but seemed to reach the maximum $q_{u}$ after 14 days of curing. It is interesting to note that although $q_{u}$ for days 14 and 28 are similar, the rise of the compression curve indicates greater stiffness gain with longer curing time, as denoted by the steeper climb of the 28-day curve.

In Figure 4(b), the 5:5 specimen group shows a slightly different strength gain pattern, where the improvement rate in the first 2 weeks was markedly surpassed only after 28 days of curing. Indeed, the strength difference between day 7 and day 14 was about $40 \%$, while the day 28 strength was almost $60 \%$ that of 14 th day. Also, note that the increasing gradient of the initial portion of the curves clearly shows stiffening of the soil-slag specimens with time, that is, enhancement of stiffness due to solidification of the soil matrix by the steel slag.

The compression curves for specimens 3:7 are presented in Figure 4(c). It is counter-intuitive that the maximum $q_{u}$ attained $(\approx 110 \mathrm{kPa})$ after 28 days of curing was equivalent to the 14-day strength of the 5:5 specimen, Figure 4(b). One would expect more slag addition to the dredged soil to result in more significant strength improvement. This reversed effect due to large amount of slag could be explained by the transformation of the originally fine-grained soil to a semigranular soil-slag mixture. The cohesion of the soil may be enhanced by solidification with the steel slag, but the induced cementation effect seemed to be overwhelmed by segregation caused by the large quantity of coarser slag particles. Moreover, the initial rise of the compression curves of the 7-, 14-, and 28-day specimens overlapped one another, pointing to the unchanged stiffness with prolonged curing. Unlike the $3-$ day specimen with a much gentler slope, the stiffness clearly reached its maximum by day 7 . Nonetheless, the peak strength or $q_{u}$ showed continuous increment between 7 and 28 days.

The relationship between $q_{u}$ and curing period is summarized in Figure 5. Obviously, the strength gain follows a pattern as discussed above and illustrated in Figure 4. The most significant strength improvement over time was demonstrated by specimens $5: 5$, followed by $3: 7$ and $7: 3$. It is however interesting to note that while the $5: 5$ strength gain was linear relative to time, the strength gain rate was 


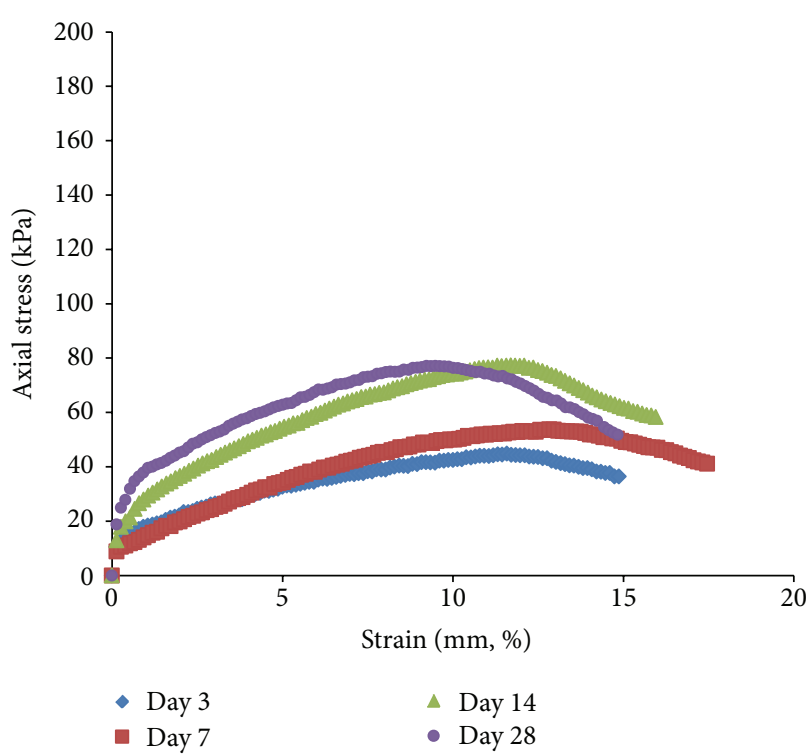

(a)

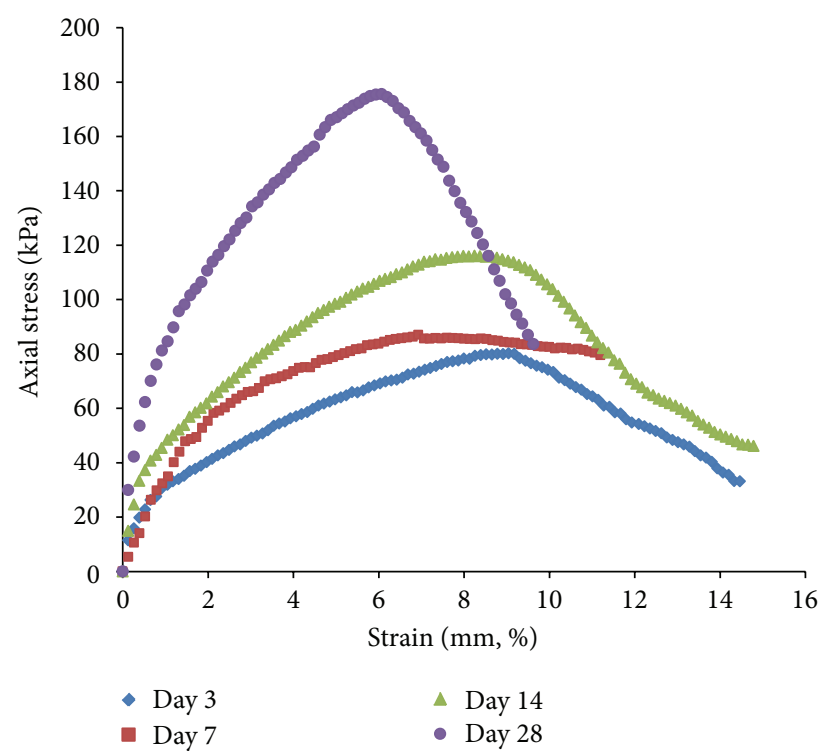

(b)

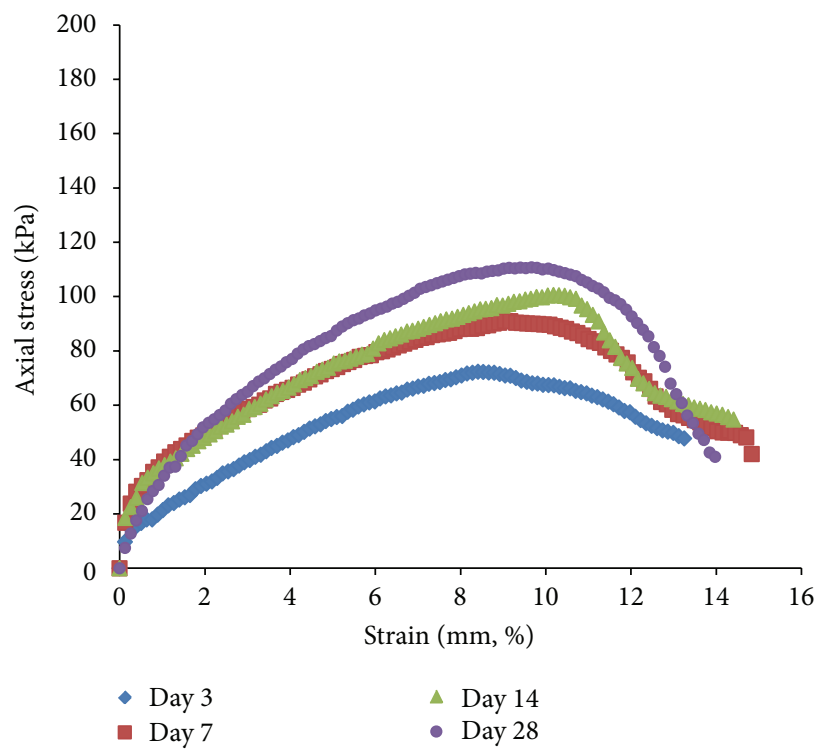

(c)

FIGURE 4: Compression curves for the solidified specimens.

similar to those of the other 2 sets of specimens. The plots lie parallel to one another within the first 7 days for specimens $3: 7$ and initial 14 days for specimens $7: 3$. This unique feature suggests gradual straightening of the $q_{u}$-time plot as the optimum mix ratio is approached, that is, $5: 5$ in this particular case. The inset in the same figure exemplifies this observation with hypothetical trend lines of various trial mix ratios approaching the optimum ratio. It also signifies long term strength gain with the optimum soil : slag ratio used, as shown by the linear rise of the 5:5 plot in Figure 5. As slag properties can vary considerably depending on the iron ore and steel-making processes, the optimum soil:slag ratio is expected to vary too, resulting in unique $q_{u}$-curing period plots with a distinct optimum ratio.

\section{Conclusions}

The overall strength improvement pattern of the soil-slag mixtures suggests an optimum slag content for the solidification's maximum efficacy to be acquired. In the present study, the dredged marine soil admixed with soil : slag ratio of $5: 5$ could produce 3 times strength improvement compared to the untreated soil in 28 days. If time is not a constraint and that a more granular mixture is desired, a 3:7 mixture left to mature for 28 days could result in similar $q_{u}$ as a 5:5 mixture at 14 days old. In short, the findings shed light on the strength gain characteristics of dredged marine soil admixed with activated steel slag. Apparently, a number of factors need to be taken into account in the mix design 


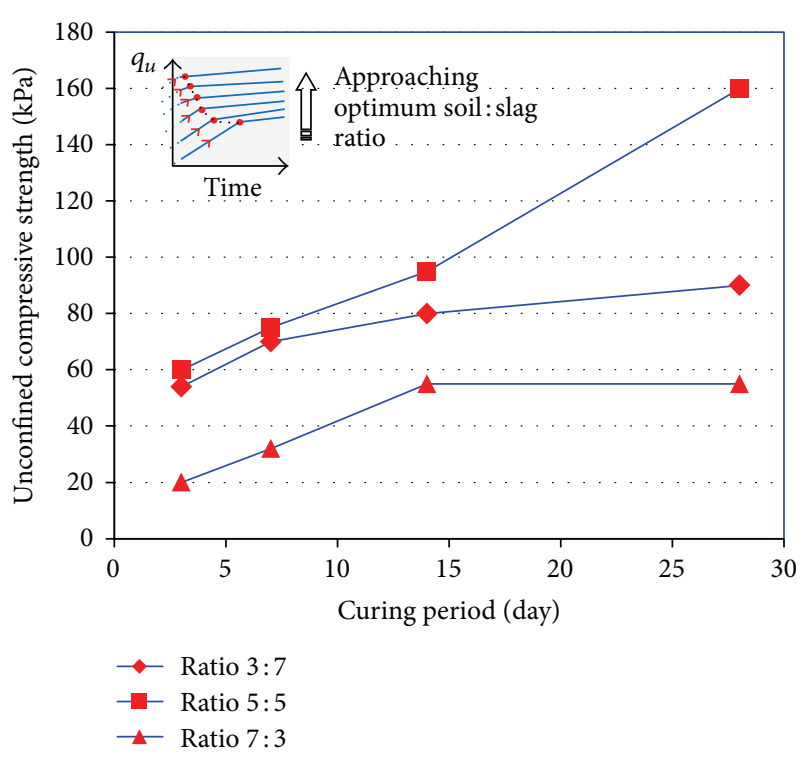

FIGURE 5: $q_{u}$-curing period.

for the best solidification effect to take place. These include the mixing water content, slag content, curing period, and the mixed material's properties required. Higher percentage of slag inclusion does not necessarily guarantee greater strength increase, as generally perceived and assumed in soil solidification.

\section{Conflict of Interests}

The authors declare that there is no conflict of interests regarding the publication of this paper.

\section{Acknowledgment}

Appreciation is also due to N.H. Hashim and R. Hamdan, as well as the technical support team at UTHM for their assistance and kind inputs.

\section{References}

[1] J. B. Herbich, Handbook of Dredging Engineering, McGraw-Hill, New York, NY, USA, 2nd edition, 2000.

[2] Nippon Slag Association, 2003, http://www.slg.jp/.

[3] Q. Wang and P. Yan, "Hydration properties of basic oxygen furnace steel slag," Construction and Building Materials, vol. 24, no. 7, pp. 1134-1140, 2010.

[4] H. Y. Poh, G. S. Ghataora, and N. Ghazireh, "Soil stabilization using basic oxygen steel slag fines," Journal of Materials in Civil Engineering, vol. 18, no. 2, pp. 229-240, 2006.

[5] P. L. A. Erftemeijer, B. Riegl, B. W. Hoeksema, and P. A. Todd, "Environmental impacts of dredging and other sediment disturbances on corals: a review," Marine Pollution Bulletin, vol. 64, no. 9, pp. 1737-1765, 2012.

[6] UK Marine Special Areas of Conservation, Dredging and Disposal, 2001, http://www.ukmarinesac.org.uk/.
[7] D. Yell, Dredging: ICE Design and Practice Guide, Thomas Telford Services, London, UK, 1995.

[8] A. Lindmark, A. Wilhelmsson, and A. B. Cowi, Stabilization of Contaminated Sediments: A Comparison of Shear Strength from Laboratory Mixing and Testing and Field Testing, Linnaeus EcoTech, 2012.

[9] K. Siham, B. Fabrice, A. N. Edine, and D. Patrick, "Marine dredged sediments as new materials resource for road construction," Waste Management, vol. 28, no. 5, pp. 919-928, 2008.

[10] J. L. Childs, Concepts, Methods and Measures for Achieving Beneficial Use of Dredged Material: Managing DM for Beneficial Purpose, USACE ERDC, 2013.

[11] C. Shi, "Steel slag-its production, processing, characteristics, and cementitious properties," Journal of Materials in Civil Engineering, vol. 16, no. 3, pp. 230-236, 2004.

[12] A. A. M. Al Bakri, H. Kamarudin, A. K. Omar, M. N. Norazian, C. M. Ruzaidi, and A. R. Rafiza, "The effect of alkaline activator ratio on the compressive strength of fly ash-based geopolymers," Australian Journal of Basic and Applied Sciences, vol. 5, no. 9, pp. 1916-1922, 2011.

[13] Y. Liang, W. Li, and X. Wang, "Influence of water content on mechanical properties of improved clayey soil using steel slag," Geotechnical and Geological Engineering, vol. 31, no. 1, pp. 83-91, 2013.

[14] J. M. Manso, V. Ortega-López, J. A. Polanco, and J. Setién, “The use of ladle furnace slag in soil stabilization," Construction and Building Materials, vol. 40, pp. 126-134, 2013.

[15] D. G. Grubb, M. Wazne, S. C. Jagupilla, and N. E. Malasavage, "Beneficial use of steel slag fines to immobilize arsenite and arsenate: slag characterization and metal thresholding studies," Journal of Hazardous, Toxic, and Radioactive Waste, vol. 15, no. 3, pp. 130-150, 2011.

[16] C.-M. Chan, T. A. Mizutani, and Y. Kikuchi, "Reusing dredged marine clay by solidification with steel slag: a study of compressive strength," International Journal of Civil and Structural Engineering, vol. 2, no. 1, pp. 270-279, 2011.

[17] C.-M. Chan, "Influence of mix uniformity on the induced solidification of dredged marine clay," Environmental Earth Sciences, vol. 71, no. 3, pp. 1061-1071, 2014.

[18] B. M. Das, Principles of Geotechnical Engineering, Cengage Learning, Boston, Mass, USA, 7th edition, 2010.

[19] J. Lai, Unconfined Compression Test, Department of Construction, Chaoyang University of Technology, Taichung, Taiwan, 2007. 

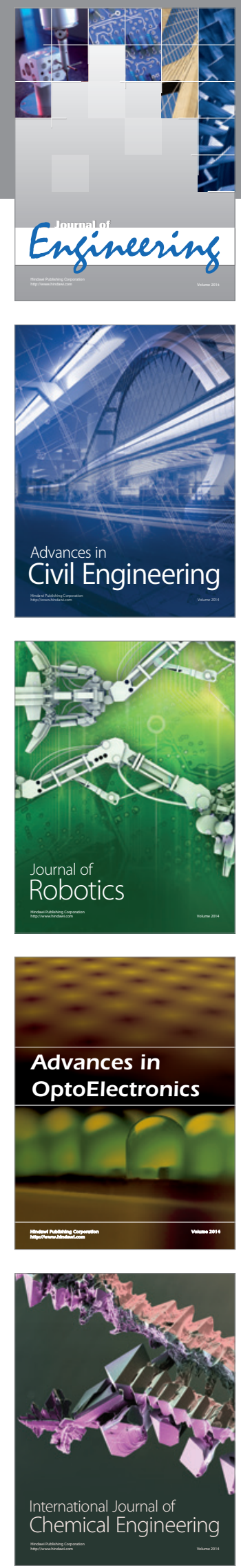

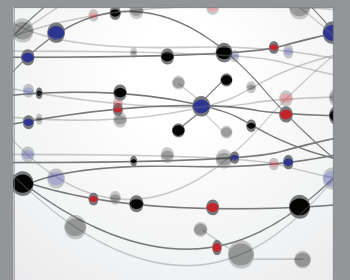

The Scientific World Journal
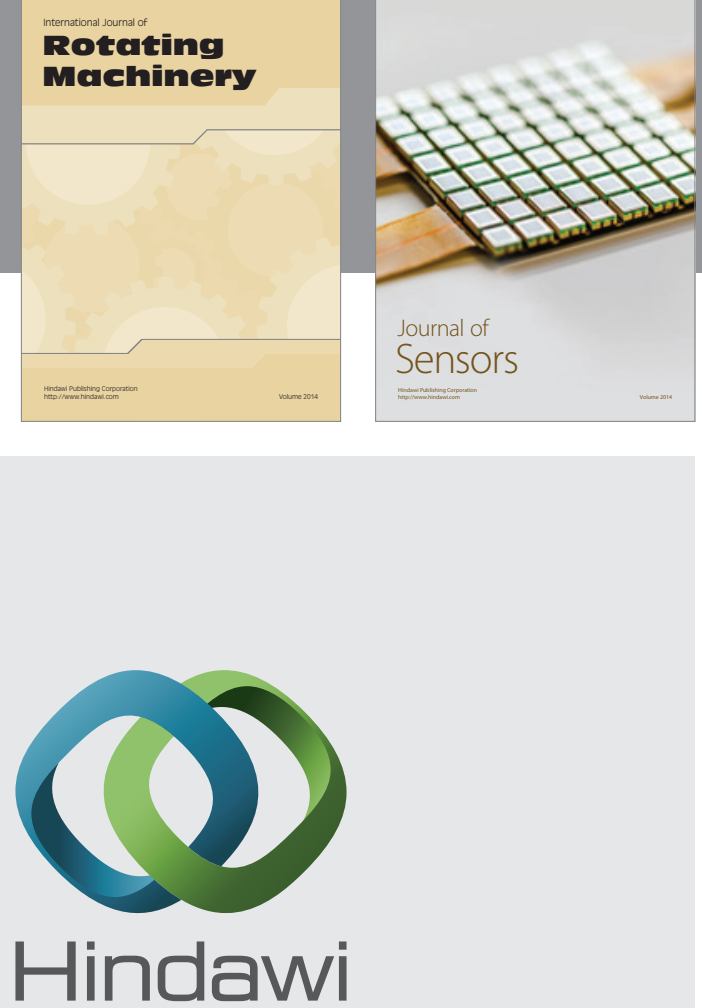

Submit your manuscripts at http://www.hindawi.com
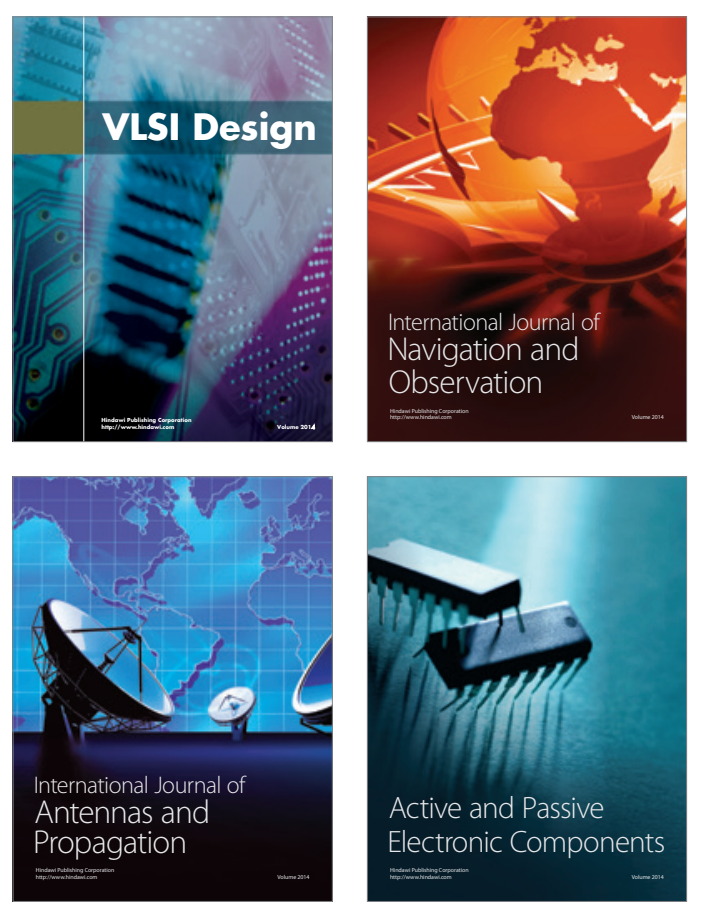
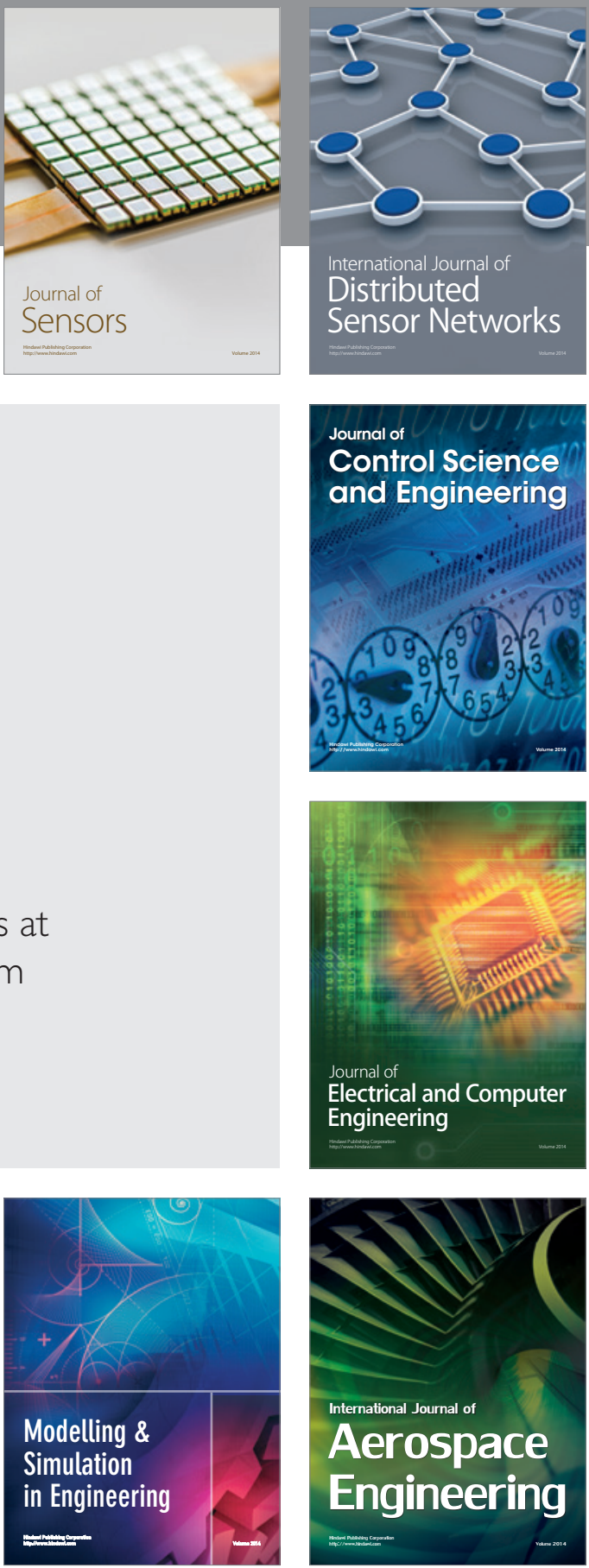

Journal of

Control Science

and Engineering
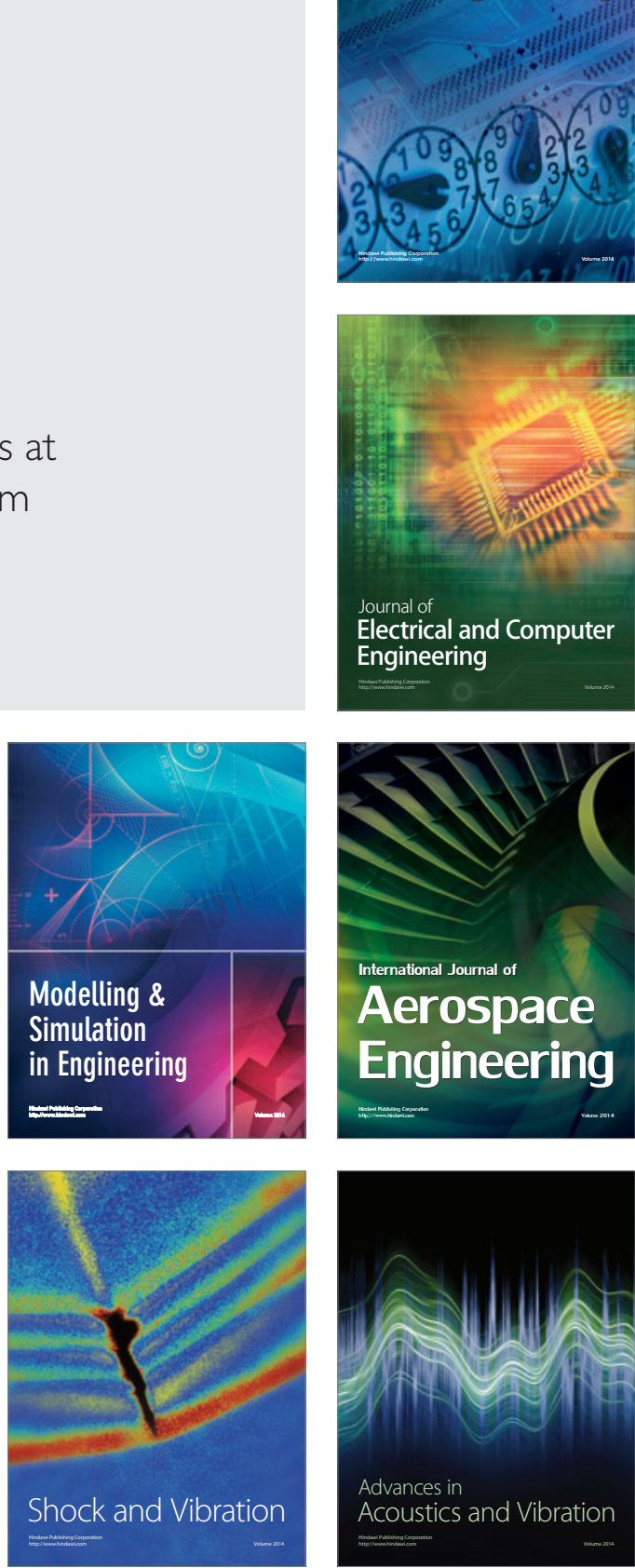